\title{
IMPACT OF THE GLOBAL FINANCIAL CRISIS ON THE INDUSTRY OF FESTIVAL, CONCERT AND CLUB TOURISM IN POLAND
}

\author{
MiCHAŁ NiEWIADOMSKI, ${ }^{1}$ JAKUB PIECUCH ${ }^{2}$
}

\author{
University of Agriculture in Cracow, POLAND \\ 1e-mail: michal@niewiadomski.li \\ 2 e-mail: j.piecuch@ur.krakow.pl
}

\begin{abstract}
KEYWORDS | events, economy, tourism, financial crisis
ABSTRACT $\quad$ The essence of problem presented in this article is to verify hypothesis referring to 2008 financial crisis negative influence on the tourism industry, related to musical events in Poland. The analyzed data range include the period from 2003 to 2014 and 2007 to 2014. The introduction presents theoretical basis of 2008 financial crisis. First part of paper contains the analysis methods. The second chapter reveals numerical investigation results. The statistical researches was based on data collected from the Central Statistical Office in Poland. In third part, author discusses the subject with investigators in similar areas of interests and concludes the work results.
\end{abstract}

\section{Introduction}

"Financial crises are situations in which are undergoing rapid changes in the financial markets. Negative transformations are connected with insufficient financial liquidity, the insolvency of market entities and reduced production" (Szymański, 2001, pp. 119-120). In consequence of changes resulting from the crisis is the crash of the financial market functions which are related to the inefficient allocation of capital funds. 
Economic impasse of United States of America was caused by the granting of mortgages for people who could not afford to repay them. As a result of the sale of structured bonds by European banks, the crisis moved into the Europe. Thanks to it the bond market collapsed, banks were being held the securities and due to a drop in demand could not sell it own assets.

In the early stages the crisis avoided the Polish economy, so the actual impacts were felt only in 2009. Polish banks reduced lending. There has been speculation which made the zloty lower. What is more, there were financial problems of some companies with currency options (Forsal.pl, 2009).

Troublesome consequence of crisis was to reduce lending to businesses and individual customers. This was caused by a lack of confidence in the global financial system. Polish banks have tightened its own lending criteria, the main reason of lending policy was to regain the confidence of customers which decreased domestic demand in the country (also consumer). Apart from the negative consequences of the financial crisis that influenced on corporations involved in organizing musical events, the effects of the crisis changed the tourism economy which means "the activity of economic entities, which do not create typical tourist products" (Panasiuk, 2008, p. 24). The functioning of these companies is not dependent on tourism but it is additional operation, although in some cases it may happen that at a certain time (tourist season) those benefits are predominant. The tourism product in a narrower sense is everything that is bought by the tourist customer. In the broader sense it is everything he does during the travelling and staying in touristic place. Therefore, a reduction in tourist traffic not only in the tourism industry of music events but in the whole sector causes depletion of society (Altkorn, 1994, pp. 97-98).

\section{Data and research methods}

To read the relationship between the impact of the financial crisis and its reaction on the tourism industries of the festival, concert and club music events in Poland, the researcher used the basic statistical indicators. They describe the measure of central tendency, analyze the dynamics and variability of individual phenomena and estimate the correlations between variables. Basic instruments used in the statistical analysis:

- analysis of the dynamics of phenomena: the absolute increase, the absolute chain increase, the relative increase, the relative chain increase,

- measures of location: the arithmetic mean,

- measures of variation: the standard deviation, coefficient of variation (Wawrzynek, 2007, p. 37),

- dependence measures: Pearson correlation coefficient (Pearson, 1895, pp. 240-242),

- Pearson correlation matrix, the multiple correlation coefficient (Buda, Jarynowski, 2010, p. 2).

In the study of the effects caused by the financial crisis on the industry of tourism festival, concert and club music events in Poland, was used data from the Central Statistical Office in Poland (in the studied years): average monthly gross wage, the rate of inflation and the phenomena 
associated with these forms of activity, assuming invariance other economic and demographic factors. Access to records from the years 2003-2014 allows to observe changes in the studied cases that negatively affected the tourism industry.

\section{Resullts}

Statistical analysis was carried out in the group: the cultural centers, clubs and community centers at years 2003-2014. The Central Statistical Office shares data about the number of the artistic groups, events, participants, performances of amateur and professional groups, figures for the music clubs on Polish territory.

By examining data on the number of artistic groups (in comparison to 2007) in the period 2003-2014, it is noted that their number is growing till the year 2009. After 2009 there was a breakdown in the trend of phenomenon. In 2011 the number of artistic groups fell down by $-19 \%$ and in 2012 by $-12 \%$. Analyzing the number of events in 2003 and 2005 in comparison to 2007 it can be noticed that their number was increasing to 2009. The rapid growth of the phenomenon occurred in 2009. The number of events in 2011 was decreased by $12 \%$ and in 2012 by $7 \%$ comparatively to the base year 2007. From 2003 to 2009 (against to 2007) the number of participants was being increased during the events. In 2011 and 2012 the number of participants was dropping by $9 \%$ and $6 \%$ (Table 1).

Table 1. The absolute increase including the number of artistic groups, events, participants in Poland at years 2003-2014 (base period adopted in 2007)

\begin{tabular}{lcccccccc}
\hline \multicolumn{1}{c}{ Specification } & 2003 & 2005 & 2007 & 2009 & 2011 & 2012 & 2013 & 2014 \\
\hline Artistic groups & 15,533 & 17,382 & 17,454 & 18,302 & 14,092 & 15,330 & 15,514 & 15,656 \\
\hline Increase (\%) & -11 & 0 & - & 5 & -19 & -12 & -11 & -10 \\
\hline Events & 208,447 & 208,853 & 209,984 & 237,929 & 185,714 & 195,070 & 206,091 & 221,173 \\
\hline Increase (\%) & -1 & -1 & - & 13 & -12 & -7 & -2 & 5 \\
\hline Participants & $30,213,027$ & $32,283,418$ & $33,612,049$ & $34,455,370$ & $30,750,339$ & $31,483,578$ & $38,106,066$ & $40,303,742$ \\
\hline Increase (\%) & -10 & -4 & - & 3 & -9 & -6 & 13 & 20 \\
\hline
\end{tabular}

Source: own study based on CSO data, http://stat.gov.pl/bdl.

The graph below (Figure 1) shows the percent change in the analyzed phenomena over the years 2003-2014 in comparison with the base year 2007. It is a graphical representation of the table previously considered in order to show better effects of research. The figure shows that in 2009 the number of artistic groups, parties and participants of the events was growing. From 2009 to 2011 it is observed a considerable decrease in studied phenomena.

In order to confirm the relationship of the analyzed phenomenon the correlation coefficients were investigated between the number of artistic groups and the number of events, the number of artistic groups and the number of participants of events in Poland at years 2003-2014. The above factors are about 0.8774968 and 0.88061997 which means a strong relationship. If the condition 
number of artistic groups increase the number of events will increase while the number of artistic groups will decrease, the number of parties decrease and vice versa. The rise of amount of artistic groups cause the increase in the number of participants during the events, a decrease of artistic groups will generate a loss in the number of participants at the events and vice versa.

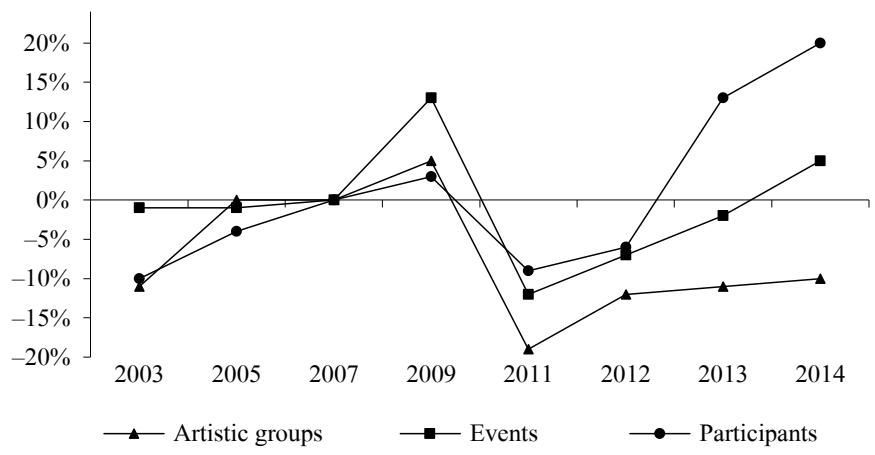

Figure 1. Graphic illustration of the percentage variability of the number of artistic groups, events, participants of the events in Poland at years 2003-2014 (base period adopted in 2007)

Source: see tab. 1.

Testing the Pearson correlation matrix was obtained an indicator equal to 0.05 . In consequence the study shows that the degree of correlation between the number of artistic groups, events and participants at the events in Poland is very high. This means that an increase or reduction in amount of the mentioned above phenomena will cause analogue reactions on the other. Additionally, thanks to the multiple correlation coefficients examination the presence of the strong relationship was confirmed between the measured trait.

The number of performances of the amateur artistic groups fell down in 2009 by $14 \%$ and in 2011 by $28 \%$ (in comparison to 2007). The highest decrease in the number of participants during the events with performances of amateur groups compared to the base year was confirmed in 2011, it was equal 35\% (Table 2). In 2009 comparatively to 2007 the decrease was smaller, it was 19\%.

Assuming 2007 as the base year it can be observed it was smaller number of performances by professional groups in 2011 by 13\% and 9\% in 2012. From 2007 to 2009 it was noticed an increase in the number of performances by $7 \%$. This was related to professional actions of the groups, and early booking deadlines of the shows by stakeholders. Very large reduction in the figure of participants during events with the participation of professional groups performances, up by $19 \%$ was taken in 2011 (compared to 2007). Comparatively fewer participants (17\%) were participated in performances in 2012. The lowest decline in artistic groups performances was observed in 2009 equal to $4 \%$ (Table 2).

The year 2007 is the year of largest number of club events in Poland (2012). In the following years 2009, 2011 and 2012 it was found a decrease in the number of events by $27 \%, 43 \%$ and $46 \%$ 
(in comparison with the base year). The number of participants decreased gradually from 2007 to 2012. The lowest numerical status of the people involved in the events recorded in 2012, it was equal to 691850 participants, it was up to 50\% less comparatively with 2007. Statistical data from 2011 is not much different from that of 2012. In 2011, 48\% of participants were disappeared from club events in comparison with the base year. In 2009, the number of events in relation to 2007 was decreased by $31 \%$ (Table 2 ).

Table 2. Single base relative increases (on a constant basis), of the number of amateur groups performances in Poland in the years 2007-2014 (the base period adopted in 2007)

\begin{tabular}{lcccccc}
\hline \multicolumn{1}{c}{ Specification } & 2007 & 2009 & 2011 & 2012 & 2013 & 2014 \\
\hline Number of amateur groups performances & 49,689 & 42,860 & 36,001 & 36,767 & 36,023 & 35,324 \\
\hline Increase (\%) & - & -14 & -28 & -26 & -27 & -29 \\
\hline $\begin{array}{l}\text { Number of the participants with participation } \\
\text { of amateur groups performances }\end{array}$ & $9,901,997$ & $7,981,047$ & $6,479,440$ & $6,544,567$ & $6,314,146$ & $5,617,295$ \\
\hline Increase (\%) & - & -19 & -35 & -34 & -36 & -43 \\
\hline Number of professional groups performances & 23,687 & 25,428 & 20,526 & 21,469 & 21,061 & 21,427 \\
\hline Increase (\%) & - & 7 & -13 & -9 & -11 & -9 \\
\hline $\begin{array}{l}\text { Number of participants with participation } \\
\text { of professional groups performances }\end{array}$ & $11,124,817$ & $10,628,352$ & $8,982,252$ & $9,228,489$ & $7,558,979$ & $7,692,904$ \\
\hline Increase (\%) & - & -4 & -19 & -17 & -32 & -31 \\
\hline Club events & 15,555 & 11,419 &, 8789 & 8,392 & 8,071 & 7,805 \\
\hline Increase (\%) & - & -27 & -43 & -46 & -48 & -50 \\
\hline Number of participants during the club events & $1,379,761$ & 948,393 & 714,594 & 691,850 & 619,743 & 654,670 \\
\hline Increase (\%) & - & -31 & -48 & -50 & -55 & -52 \\
\hline
\end{tabular}

Source: see tab. 1

An important category in the examination of the impact of financial crisis on tourism and musical events industry is income which means "the primary obstacle limiting the ability to achieve objectives and needs of man" (Oyrzanowski, 1995, p. 241). Financial income determines the maximum that can be spent on the purchase of goods and services. On the broader to meet the needs that can be afforded with increasing income.

In researches of gross income of Polish citizens, it is necessary juxtaposition with the expected inflation rate. It was noted that over the years 2007-2012 the prices of products and services increased by $20 \%$. In 2009 it was observed an increase of $8 \%$, in 2010 by $11 \%$ and in 2011 by as much as $16 \%$ (compared to 2007). In order to compare the price level of 2003 and 2012, the growth rate calculations were performed on prices of goods and services in the period 2001-2006 compared to the base year 2001. In 2006 compared with 2001, prices rose by only $10 \%$. In 2012 compared to 2007 it was $20 \%$.

Data on the rate of inflation was applied for the period corresponding to a gross income of the Polish population. It was assumed that the rate of 100 in 1998 has been treated as 100 PLN, that a potential buyer wants to spend on a ticket to go to the concert. The same ticket which in 1998 cost 100 PLN in 2012 increased its value to approx. 168.5 PLN. The assumptions include the fact that 
it is a gross salary. Net income is impossible to calculate due to the fact that not all Polish citizens are covered by one tax rate. In 1998, a ticket to the concert cost 100 PLN (hypothetically) in 2002, the same ticket could be purchased for approx. 127 PLN. If in 2002 the entire salary was allocated for buying a ticket it would be affordable only for 17.6 tickets. Until 2007, the increase in wages has enabled the purchase of five tickets more, the price of the ticket in 2008 was equal to 145 PLN. From 2008 to 2012, it could be afforded to buy about 22 tickets.

\section{Discussion and conclusions}

Considering the observations which included the number of artistic groups, events and amount of participants in events, it was noticed that between 2003 and 2009 it was an upward trend. In 2011 there was a noticeable decline in all the above-mentioned phenomenon (comparatively to the base year 2007).

From the analysis of dynamics conclusions can be drawn about regarding increases or decreases the value of the phenomenon. By examining the number of performances of amateur groups, it was found that the greatest decrease in comparison to 2007 took place in 2011 and it was equal to $28 \%$. At the same time, the number of participants in the events with the participation of professional groups has decreased compared to 2007 by as much as $35 \%$.

The most important part of the research process was to identify a factor that influenced the reduced figures on the previously discussed phenomenon in late 2009-2011. The reason for the crisis in the tourism industry music events in Poland could be unfavorable ratio of increase in the gross income of the citizens to higher prices of goods and services market.

Analysis of the average monthly gross wages and inflation showed that from 2008 to 2012 it could be afforded a similar amount of goods and services. It is worth adding that the amount of goods and services that can be purchased rose from 2003 to 2007 and continuously since 2008 it has seen its stabilization.

In the literature, there are a huge amount of positions which analyze the 2008 financial crisis impact on a different tourism sectors. An interesting subject approach was presented by M. Borza, who demonstrates a significant role of tourism services prices in tourist arrivals case. During the crisis time, prices of services should be reduced, it could stimulate the tourist traffic (Borza, 2010).

Investigating the 2008 financial crisis impact it is worth to take a closer look on smaller territorial units. Particularly interesting are less developed regions. In case of crisis situation, the areas which support domestic tourists suffer the most. Those regions should be assisted through economic policy instruments. The recovery of less developed territories is much more difficult than areas which are hosting foreign tourists (Papatheodorou, Arvantis, 2014, p. 201).

One of crisis solutions could be suitable tourism offer preparation, focusing on niche tourism, which has become increasingly popular and it is not exploited (Manolică, Roman, 2011, pp. 418423). Therefore, financial and organizational support, directed toward local artists and projects could effectively stimulate markets. Tourism growth creates new jobs and leads to infrastructure development (Kapiki, 2012, pp. 19-30). 
Interesting way in order to deal with crisis situation is presented by V. Urban and I. Verhaegen, who claims that a very important factor in tourism expansion is the offered quality of services. In comparison to the compensate crisis negative effects, the tourism services standards should be increased. Moreover, appropriate marketing and advertising techniques to promote the attractions, events and tourist regions should be implemented. Important role in tourism development act the organizational sphere which optimally valorizes tourism potential (Urban, Verhaegen, 2011, pp. 195-196).

The unique research approach is to compare data describing phenomenon quantitatively with the stock market indicators. Macao gambling tourism analysis revealed a strong dependence of the Hang Seng Index with entertainment tourist sector incomes (Chan, 2011, pp. 328-329). On this basis, the possibility of forecast changes in tourism is concluded. Similar analyzes enable the rapid reaction possibility, in order to rescue tourism sectors in the future.

Referring to published article titled Tourism, Festivals and Cultural Events in Times of Crisis on March 30, 2012, developed under the leadership: Lise Lyck, Phil Long and Allan Xenius Grige from the Copenhagen Business School it has been noted that in some countries, festivals and events were seen as a tool to accelerate the development of the economy (France, Canada) (Lyck, Long, Grige, 2012, pp. 3-5). The results show that the financial crisis had a significant impact on the Polish economy and in particular the tourism sector services related to the tourism industry of music. Referring to introduction of the work it can be concluded that enterprises due to lack of liquidity associated with the granting of the loans appeared stagnation in creating new goods and services. Because of the crisis, many companies have given up from creating forms of music tourism to other business instead. The other corporations made the cost lower. Thanks to it the attractiveness of tourism music industry was also reduced.

\section{Referencess}

Altkorn, J. (1994). Marketing w turystyce. Warszawa: PWN.

Borza, M. (2010). The Effects of Financial Crisis on Tourism Market. Available at: http://www.mbf-eu.info/Files/415f6d76d58e-449a-b451bc854e406c6e/paper_BORZA.pdf(12.06.2016).

Buda, A., Jarynowski, A. (2010). Life-time of correlations and its applications. Warszawa: Wydawnictwo Niezależne.

Chan, V.K.Y. (2011). The Impact of the Global Financial Crisis on the Entertainment Tourism Industry: A Financial Engineering Case Study of Macao from 2007 to 2010. Systems Engineering Procedia no. 1, Amsterdam: Elsevier B.V.

Forsal.pl (2009). PKB Polski rośnie, a Unii spada. Available at: http://forsal.pl/artykuly/348843,pkb_polski_rosnie_a_ unii_spada.html (19.05.2014).

Kapiki, S. (2012). The Impact of Economic Crisis on Tourism and Hospitality: Results from a Study in Greece. Central European Review of Economics and Finance, 2 (1).

Lyck, L., Long, P., Grige, A. (2012). Tourism, Festivals and Cultural Events in Times of Crisis. Copenhagen: Copenhagen Business School Publications.

Manolică, A., Roman, T. (2011). Romanian Tourism in the Curent Economic Crisis. Review of International Comparative Management, 1 .

Oyrzanowski, P. (1995). Mikroekonomia. Kraków: Wydawnictwo Profesjonalnej Szkoły Biznesu.

Panasiuk, A. (2008). Gospodarka turystyczna. Warszawa: PWN. 
Papatheodorou, A., Arvantis, P. (2014). Tourism and the Economic Crisis in Greece-Regional Perspectives. Région et Développement, 39.

Pearson, K. (1895). Notes on regression and inheritance in the case of two parents. Proceedings of the Royal Society of London, 58.

Szymański, W. (2001). Globalizacja: wyzwania i zagrożenia. Warszawa: Difin.

Urban, V., Verhaegen, I. (2011). The Influence of Economic and Financial Crisis on Tourism Services in Romania. Economy Transdisciplinarity Cognition, 14 (1).

Wawrzynek, J. (2007). Metody opisu i wnioskowania statystycznego. Wrocław: Wydawnictwo Akademii Ekonomicznej imienia Oskara Langego we Wrocławiu.

\section{WPŁYW GLOBALNEGO KRYZYSU FINANSOWEGO}

NA BRANŻĘ TURYSTYKI FESTIWALOWEJ, KONCERTOWEJ I KLUBOWEJ

W POLSCE

SŁOWA KLUCZOWE

STRESZCZENIE wydarzenia, ekonomia, turystyka, kryzys finansowy

Istotą problemu pracy była weryfikacja hipotezy dotyczącej negatywnego wpływu „kryzysu finansowego 2008” na branżę wydarzeń turystyki muzycznej w Polsce. Badania dotyczyły lat 2003-2014 oraz 2007-2014 i przeprowadzono je na podstawie danych Głównego Urzędu Statystycznego w Polsce. We wstępie przedstawiono przyczyny wybuchu kryzysu finansowego w 2008 roku; w pierwszej części opisano wykorzystane metody badawcze zjawisk liczbowych, a w drugim rozdziale - wyniki analiz statystycznych. W trzecim rozdziale autor podjął dyskusję z poglądami zajmujących się analogiczną tematyką naukowców oraz przedstawił wnioski dotyczące wyników badań. 